\title{
Klumme: Politisk ledelse må opjusteres
}

\author{
Af Hugo Gaarden
}

Politisk ledelse må opjusteres. Der er behov for, at toppen af erhvervslivet engagerer sig langt stærkere i politik - også globalt - for at få stærkere beslutningskraft og mere langsigtede beslutninger.

Bortset fra i Kina findes den mest erfarne og veludviklede ledelseskraft i erhvervslivets top og ikke i magtens centrum - politik. Det er blevet et problem i den vestlige verden, hvor både populisme og hæsblæsende forandring skaber behov for at opjustere den politiske ledelse.

En stærkere inddragelse af dygtige erhvervsledere i politik kan blive et afgørende skridt. Verden er kommet i en paradoksal situation, fordi menneskets overlevelse kan afhænge af, at ikke-valgte militære ledere forhindrer den valgte politiske leder i verdens største nation, USA, i at træffe den beslutning, han ønsker. De militære ledere kan i givet fald spænde ben for præsidentens forsøg på at bruge atomvåben eller at gennemføre et militært angreb på Nordkorea. Stabschefen, den nationale sikkerhedschef og forsvarsministeren kan gå til offentligheden og Kongressen og dermed tvinge præsidenten til at ændre kurs. Men problemet er i virkeligheden langt mere omfattende. Den tyske ugeavis Die Zeit havde for nylig en tankevækkende artikel, skrevet af René Obermann, der er direktør i London i det amerikanske globale investeringsselskab Warburg Pincus, som har den tidligere amerikanske finansminister Timothy Geithner som bestyrelsesformand.

Obermann er dybt bekymret over splittelsestendenser i Europa med negative sociale konsekvenser, voksende ulighed, skandaler i erhvervslivet som dieselskandalen, manglende politisk vilje til at tvinge koncerner til at betale skat og manglende investeringer i uddannelse.

Han hæfter sig ved, at Europa reelt er en supermagt på grund af sin økonomiske størrelse og på grund af de værdier, Europa bygger på. De skal blot samles og gøres til en langt stærkere og mere synlig faktor, end det sker i dag, ellers kan Europa ikke komme på omgangshøjde med USA og Kina, og heller ikke løse de interne problemer. Da der er en voksende erkendelse af, at vi har et ledelsesproblem i de vestlige demokratier, er det derfor værd at overveje, om ikke virk-

\section{Hugo Gaarden er freelance journalist.}


somhedsledere skal inddrages langt mere i den politiske beslutningsproces, ligesom de fx inddrages i arbejdsmarkedsforhandlinger i de nordeuropæiske lande. En debat om det vil svare til dén som en gruppe tidligere ambassadører rejste i bogen Danmark og Verden. Den tidligere EU-ambassadør, Poul Skytte Christoffersen, kritiserede politikerne for konstant at udsætte afgørelsen om et fuldt EU-medlemskab, for derved får man ingen indflydelse på, hvor Europa går hen. Tidligere ambassadør i Moskva, Per Carlsen, hæftede sig ved, at vi er ved at glemme de baltiske lande, hvor Danmark gik helt i front for at hjælpe dem ind i friheden.

Netop nu står Europa over for gennemgribende forandringer, begyndende med reformer af eurozonen, og derfor er ambassadørernes opråb mere aktuelle end nogensinde. Som en højtstående diplomat sagde det på Udenrigsministeriets årlige møde med offentligheden i august, så er der stort set ingen debat i Danmark om europæiske udfordringer og visioner. Problemet er, at det gælder i mange af de europæiske lande.

Dermed er vi tilbage ved problemet med den politiske ledelses kvalitet. Det illustreres i denne tid i både Storbritannien og Spanien. Briterne stemte sig ud af EU, men for hver uge vokser frustrationerne over beslutningen i takt med, at de barske konsekvenser går op for briterne. Premierminister Theresa May forsøger at være kompromisvillig, men har også en plan-B for en udtræden uden en aftale. Er det stærk ledelse?

Hverken den spanske regering eller EU har tydeligt sagt til Cataloniens befolkning, at et løsrevet Catalonien ikke kan blive medlem af EU. Politikerne har svært ved at forklare forskellen på Brexit, Skotland, Catalonien og Kosovo. EU-landene, herunder Danmark, var hurtige til at støtte de nye selvstændige lande i det tidligere Jugoslavien, men regioners løsrivelsesforsøg og brud på gængse EU-regler som i Ungarn kan kaste EU ud i nye kriser.

USA har et ledelsesproblem omkring Nordkorea og Iran. Det er aldrig før sket, at en vestlig leder har truet et land med 'total ødelæggelse', som Trump har udtrykt sig over for Nordkorea. Det er aldrig tidligere set, at en amerikanske præsident har sagt til sin udenrigsminister, at dialog er spild af tid.

Problemet for verden er, at Nordkorea med sikkerhed vil udvikle et fuldt fungerende atomvåben, der kan true USA. Hvad gør USA og det internationale samfund ved den kendsgerning? Trump vil gerne bryde atomaftalen med Iran, men han tør formentlig ikke tage skridtet, for så ventes Iran at genoptage sit atomvåbenprogram, og det vil uvægerligt føre til nye konflikter i Mellemøsten. Men han kan forsøge at presse Iran og tvinge europæiske virksomheder til at holde sig fra Iran. Spørgsmålet bliver, om EU-landene tør fastholde åbningen over for Iran og tør tage konfrontationen med Trump, som det er sket med klima-aftalen.

Europæiske erhvervsledere erkender, at de må kunne fungere rimeligt gnidningsløst i hele verden trods politiske stridigheder. De erkender også, at de må løse globaliseringens og ulighedens problemer. Hvis det sker i samspil med en revitaliseret politisk ledelse, kan den europæiske ledelses- og samfundsmodel 